\title{
Studies on the Interaction of Mycobacterium microti and Mycobacterium lepraemurium with Mouse Polymorphonuclear Leucocytes
}

\author{
By C. C. SMITH, R. M. BARR AND J. ALEXANDER \\ National Institute for Medical Research, The Ridgeway, Mill Hill, London NW7 1 AA
}

(Received 22 November 1978)

\begin{abstract}
When polymorphonuclear leucocytes (PMN) elicited in mice were infected with $M y c o-$ bacterium microti or Mycobacterium lepraemurium, phagosome-lysosome fusion occurred with both species. This contrasts with the situation in macrophages where phagosomelysosome fusion is inhibited by $M$. microti but not $M$. lepraemurium. No evidence was found for killing of $M$. microti or $M$. lepraemurium when the bacteria were isolated from PMN and their viability tested in cell-free medium or macrophages.
\end{abstract}

\section{INTRODUCTION}

Intracellular parasites which survive in macrophages interact with the vacuolar system of the host cells in a variety of ways. Mycobacterium lepraemurium (Brown et al., 1969) and Leishmania mexicana (Alexander \& Vickerman, 1975) can survive phagosome-lysosome fusion. Mycobacterium tuberculosis (Armstrong \& Hart, 1971), Mycobacterium microti (Hart et al., 1972) and Toxoplasma gondii (Jones \& Hirsch, 1972) inhibit the fusion process, while Mycobacterium leprae (Evans \& Levy, 1972) and Trypanosoma cruzi (Kress et al., 1975; Noguiera \& Conn, 1976) are thought to traverse the phagosome or plasma membrane and lie unbounded in the cytoplasm.

Inflammatory reactions are characterized by an influx of phagocytic cells. Initially, polymorphonuclear leucocytes (PMN) predominate and in experimental cutaneous infections with mycobacteria they ingest a large proportion of the bacteria present (Closs \& Haugan, 1975). Mycobacteria are soon released by PMN, which have a short life-span, but are rephagocytosed either by other PMN or, more likely, by mononuclear phagocytes which are the predominant cell type within $24 \mathrm{~h}$ of the development of the inflammatory reaction (Adams, 1975; Closs \& Haugan, 1975).

The present study was undertaken to determine whether M. lepraemurium or M. microti, which show contrasting phagosome-lysosome interactions in macrophages, behave similarly in PMN. The bactericidal potential of PMN alone and in co-operation with macrophages against ingested mycobacteria was assessed.

\section{METHODS}

Animals. Twelve-week female outbred albino $\mathrm{P}$ strain and inbred C57Bl mice were obtained from the National Institute for Medical Research animal unit.

Bacteria. Mycobacterium lepraemurium, Douglas strain, was isolated from infected livers of $\mathrm{P}$ strain mice using the method of Hart \& Rees (1960). Mycobacterium microti, strain OV254, was grown in a glycerol-free medium (Ungar et al., 1962) for $14 \mathrm{~d}$. Bacilli were collected by centrifugation and resuspended, prior to use, in $0.05 \%(\mathrm{w} / \mathrm{v})$ Tween 80 with $0.1 \%(\mathrm{w} / \mathrm{v})$ bovine serum albumin in $0.9 \%(\mathrm{w} / \mathrm{v}) \mathrm{NaCl}$ solution.

Preparation of PMN for electron microscopy. Albino $\mathrm{P}$ strain mice were inoculated intraperitoneally with $2 \mathrm{ml}$ sterile $1.2 \%(\mathrm{w} / \mathrm{v})$ sodium caseinate (Difco) in $0.9 \%(\mathrm{w} / \mathrm{v}) \mathrm{NaCl}$. The mice were killed by cervical 
dislocation $18 \mathrm{~h}$ later and exudates were harvested from the peritoneal cavities with $3 \mathrm{ml}$ cold medium NCTC 109 (Gibco Biocult, Glasgow, Scotland) containing 5 units heparin $\mathrm{ml}^{-1}$ and 100 I.U. penicillin $\mathrm{ml}^{-1}$. Exudates from several mice were pooled, samples were distributed to Petri dishes and $M$. microti or $M$. lepraemurium were added to give $10^{9}$ bacilli $\mathrm{ml}^{-1}$. Cultures were incubated at $37^{\circ} \mathrm{C}$ for $30 \mathrm{~min}$. The infected PMN were fixed using a modified method of Hirsch \& Fedorko (1968). Sections were cut with glass knives on an LKB ultramicrotome, stained with uranyl acetate and Reynolds' lead citrate and examined in an AEI EM801 electron microscope with an accelerating voltage of $60 \mathrm{kV}$.

Preparation of infected PMN for mycobacterial viability studies. In these experiments a number of techniques were used to harvest and infect PMN with mycobacteria. As all results obtained were similar, only representative experiments are reported. Exudates of PMN were elicited in and harvested from C57BI mice as already described. In some experiments $10^{9} \mathrm{M}$. lepraemurium or $5 \times 10^{8} \mathrm{M}$. microti were included in the eliciting inoculum. The exudates from several mice were pooled, concentrated by centrifugation at $300 \mathrm{~g}$ for $5 \mathrm{~min}$ and resuspended in medium NCTC 199 containing $25 \mathrm{mM}-\mathrm{HEPES}, 10 \%(\mathrm{v} / \mathrm{v})$ heat-inactivated horse serum (Gibco Biocult) and 100 I.U. penicillin $\mathrm{ml}^{-1}$ to give $2 \times 10^{6} \mathrm{PMN} \mathrm{m}^{-1}$.

Cells infected with mycobacteria in vivo were incubated at $37^{\circ} \mathrm{C}$ for 2 to $20 \mathrm{~h}$ in Universal bottles. Noninfected PMN were distributed in $5 \mathrm{ml}$ portions to $25 \mathrm{~cm}^{3}$ plastic tissue-culture flasks and incubated with $10^{8} \mathrm{M}$. lepraemurium or $2.5 \times 10^{7} \mathrm{M}$. microti for $1 \mathrm{~h}$ at $37^{\circ} \mathrm{C}$. The adherent cells were washed three times to remove extracellular bacilli and the infected $\mathrm{PMN}$ were incubated for a further $1 \mathrm{~h}$.

Preparation and infection of macrophage cultures. Mice were killed by cervical dislocation, their femurs were excised and the bone marrow was flushed out with medium NCTC 109 containing $40 \%$ (v/v) inactivated horse serum, 5 units heparin $\mathrm{ml}^{-1}$ and $100 \mathrm{I} . \mathrm{U}$. penicillin $\mathrm{ml}^{-1}$. Cell suspensions from several animals were pooled and $1 \mathrm{ml}$ portions were distributed to Leighton tubes and incubated at $37^{\circ} \mathrm{C}$ overnight. Non-adherent cells were removed and the monolayers were incubated at $37^{\circ} \mathrm{C}$ for 6 to $10 \mathrm{~d}$ in medium NCTC 109 containing $40 \%(\mathrm{v} / \mathrm{v})$ inactivated horse serum, $2 \%(\mathrm{v} / \mathrm{v})$ bovine embryo extract (Difco) and 100 I.U. penicillin $\mathrm{ml}^{-1}$. The established macrophage monolayers were infected by overlaying with $10^{8}$ $M$. lepraemurium or $3 \times 10^{5} \mathrm{M}$. microti for $2 \mathrm{~h}$. Excess bacilli were removed and the monolayers were washed once with medium NCTC 109 before continuing incubation in fresh culture medium.

Mycobacterial counts and viability assays. Mycobacteria were released from PMN and macrophages ultrasonically (Ultrasonic generator and transducer, $800 \mathrm{kHz}$; Luziesa Ltd, 70 Rue J. P. Timbaud, Paris, France) using suitable volumes of Tween/albumin solution for $M$. microti or $0.1 \%(\mathrm{w} / \mathrm{v}$ ) albumin for M. lepraemurium. Bacilli were counted by a modified Breed smear technique (Hart \& Rees, 1960). The viability of $M$. microti was determined by the method of Sharp (1973). Viability of $M$. lepraemurium was estimated indirectly from length distributions of stained bacilli measured with an eyepiece graticule after culture in elongation medium (Hart \& Valentine, 1963).

\section{RESULTS}

\section{Electron microscopic studies}

Mycobacterium microti and $M$. lepraemurium were rapidly phagocytosed by PMN and phagosome-lysosome fusion occurred with both species. As well as neutrophils, a large number of eosinophils were found in these preparations and these also clearly demonstrated phagosome-lysosome fusion (Fig. 1). The process of fusion was rapid and after $30 \mathrm{~min}$ more than $80 \%$ of mycobacteria were in phagolysosomes and a large number of PMN had totally degranulated. Degranulation did not occur in uninfected sodium caseinate-elicited PMN. When macrophages were present in PMN preparations, $M$. lepraemurium were found in association with phagolysosomes, whereas in 19 out of 20 separate observations $M$. microti inhibited phagosome-lysosome fusion.

\section{Mycobacterial counts and viability}

Cell exudates elicited in C57Bl mice contained a total of $0 \cdot 7 \times 10^{7}$ to $2.2 \times 10^{7}$ leucocytes of which more than $75 \%$ were PMN. The average infection rate with $M$. microti was less than 1.5 bacilli per PMN and with $M$. lepraemurium, 8 to 25 bacilli per PMN. The viability of $M$. microti isolated from either in vitro or in vivo infected PMN ranged from 77 to $103 \%$ and was never significantly different from that of corresponding untreated bacilli. $\mathrm{MycO}-$ bacterium lepraemurium recovered from PMN infected in vitro or in vivo increased in length to the same extent as untreated $M$. lepraemurium when incubated in elongation medium for 


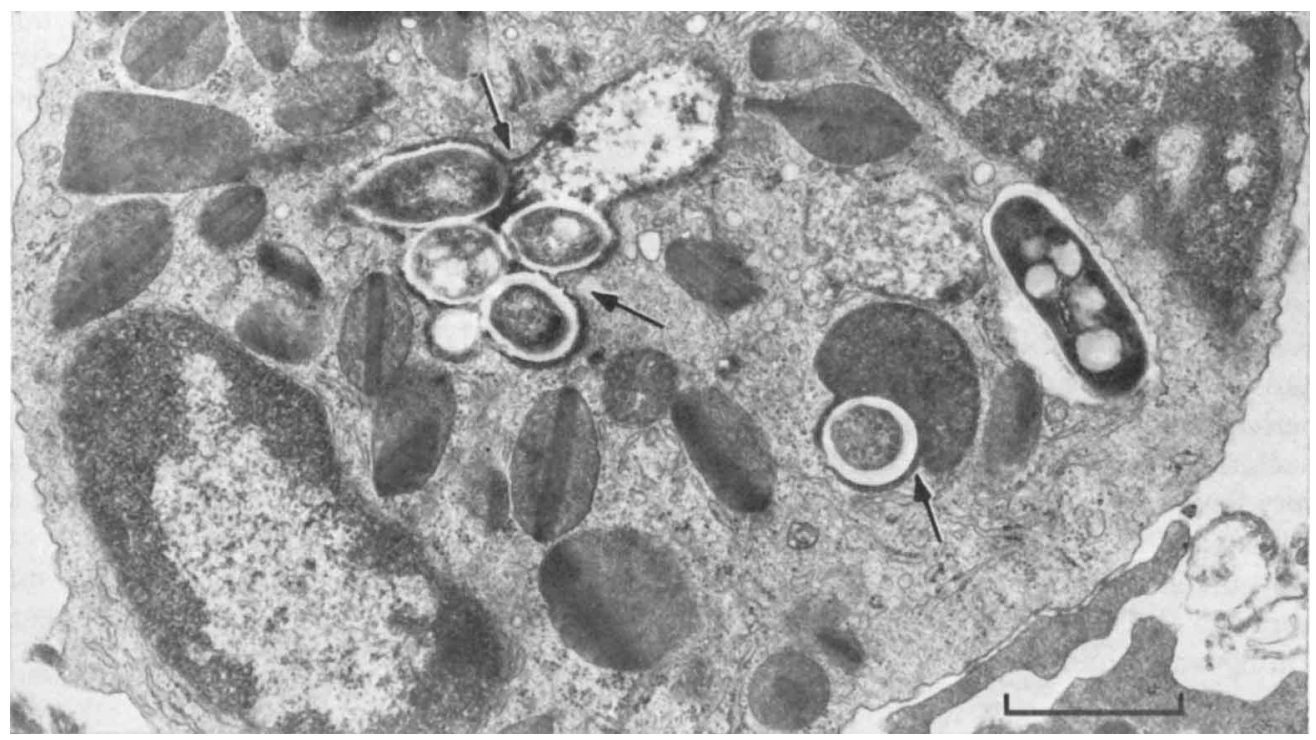

Fig. 1. An eosinophil fixed $30 \mathrm{~min}$ after infection with $M$. microti. Phagosome-lysosome fusion has occurred (arrows) in two of three phagosomes containing mycobacteria. Bar marker represents $1 \mu \mathrm{m}$.

up to $20 \mathrm{~d}$. Killed bacilli in control incubations containing $1 \%(\mathrm{v} / \mathrm{v})$ formalin showed no increase in length.

\section{Growth in macrophage cultures}

Mycobacterium microti recovered from PMN elicited in C57Bl mice with $1.2 \%(\mathrm{w} / \mathrm{v})$ sodium caseinate and infected in vivo multiplied in $\mathrm{C} 57 \mathrm{Bl}$ bone marrow macrophage cultures at the same rate as untreated $M$. microti. In a representative experiment, intracellular counts increased from $0 \cdot 7 \times 10^{5}$ bacilli per monolayer at the time of infection with PMN-derived $M$. microti to $2.86 \times 10^{5}$ bacilli per monolayer $6 \mathrm{~d}$ later, equivalent to a mean generation time of $2.95 \mathrm{~d}$. The corresponding counts for macrophage monolayers infected with untreated bacilli were $0.68 \times 10^{5}$ and $2.5 \times 10^{5}$ bacilli per monolayer, representing a mean generation time of $3.13 \mathrm{~d}$. The increase in bacterial counts was significant in each case $(P<0.01)$ but the differences in generation times between the groups were not significant. Less than $1 \%$ of bacilli present were extracellular and the generation time of $M$. microti in either fresh or macrophage-conditioned culture medium was $10 \mathrm{~d}$. Multiplication of $M$. microti in macrophage culture medium was not significant. In similar experiments, $M$. lepraemurium recovered from PMN recorded a $2 \cdot 5$-fold increase in numbers in macrophage monolayers incubated for $20 \mathrm{~d}$ compared with a $2 \cdot 2$-fold increase for untreated bacilli. The difference was not significant.

\section{DISCUSSION}

Although M. microti (Hart et al., 1972), unlike M. lepraemurium (Brown et al., 1969), inhibits phagosome-lysosome fusion in macrophages this did not happen in PMN. It seems unlikely that sodium caseinate elicitation of PMN promoted this fusion as degranulation did not occur in uninfected PMN, and in those $M$. microti infected macrophages found in the preparation phagosome-lysosome fusion had been inhibited. Little is known of the factors which induce or inhibit phagosome-lysosome fusion but the fact that $M$. microti behaves differently in PMN and macrophages suggests different mechanisms are involved.

The evidence that in vitro infected PMN were unable to kill $M$. microti directly is consistent with the findings of Hanks \& Evans (1940). The studies were extended by following the 
growth of mycobacteria recovered from PMN in cultured macrophages as this would reproduce the sequence of events in vivo. Damage of mycobacteria while in PMN could possibly make them more susceptible to killing and degradation by macrophages. However, no difference in growth in macrophages was noted between untreated mycobacteria and those recovered from PMN.

The mechanisms by which pathogenic mycobacteria survive or are killed within phagocytic cells remain largely unknown. Although $M$. tuberculosis and $M$. microti can inhibit macrophage phagosome-lysosome fusion, they survive and grow equally well when coated with antisera and phagosome-lysosome fusion occurs (Armstrong \& Hart, 1975; R. M. Barr, unpublished results). Under our experimental conditions, M. lepraemurium and $M$. microti appear to withstand exposure to PMN lysosomal enzymes. This would perhaps suggest that other mechanisms, as yet unknown, may be involved in killing mycobacteria. Infection of PMN in vivo resulted in even distributions of intracellular bacilli with very few extracellular bacteria, which ensured accurate assessment of viability. Godal et al. (1970) and R. M. Barr (unpublished results) have demonstrated that macrophages can limit the growth of small, but not large, infections with $M$. microti. Similar limitations may apply to PMN. Infection rates in these experiments were reduced to a minimum but no killing was found.

We would like to thank Dr R. J. W. Rees for his critical assessment of this manuscript and Mr D. Gregory and Ms Maureen Gardiner for excellent technical assistance.

\section{REFERENCES}

ADAms, D. O. (1975). The structure of mononuclear phagocytes differentiating in vivo. II. The effect of Mycobacterium tuberculosis. American Journal of Pathology 80, 101-116.

Alexander, J. \& Vickerman, K. (1975). Fusion of host cell secondary lysosomes with parasitophorous vacuoles of Leishmania mexicanainfected macrophages. Journal of Protozoology 22, 502-508

Armstrong, J. A. \& Hart, P. D. (1971). Response of cultured macrophages to Mycobacterium tuberculosis, with observations on fusion of lysosomes with phagosomes. Journal of Experimental Medicine 134, 713-740.

Armstrong, J. A. \& Hart, P. D. (1975). Phagosome-lysosome interactions in cultured macrophages infected with virulent tubercle bacilli. Reversal of the usual non-fusion pattern and observations on bacterial survival. Journal of Experimental Medicine 142, 1-16.

Brown, C. A., Draper, P. \& Hart, P. D. (1969). Mycobacteria and lysosomes: a paradox. Nature, London, 221, 658-660.

Closs, O. \& Haugan, O. A. (1975). Experimental murine leprosy. 3. Early local reaction to $M y c o-$ bacterium lepraemurium in $\mathrm{C} 3 \mathrm{H}$ and $\mathrm{C} 57 \mathrm{~B} 1$ mice. Acta pathologica et microbiologica scandinavica 83, 51-58.

Evans, M. J. \& LeVy, L. (1972). Ultrastructural changes in cells of the mouse footpad infected with Mycobacterium leprae. Infection and Immunity, 5, 238-247.

Godal, T., Rees, R. J. W. \& Lamvic, J. O. (1970). Lymphocyte mediated modification of bloodderived macrophage function in vitro: inhibition of growth of intracellular mycobacteria with lymphokines. Clinical and Experimental Immuno$\log y 8,625-637$.

Hanks, J. H. \& Evans, B. (1940). The action of serum, cells and blood on acid fast bacteria in vitro. I. Absence of in vitro bactericidal power against tubercle bacilli or Timothy bacilli in the serum leucocyte mixtures or the blood of normal and immunized rabbits. American Review of Tuberculosis and Pulmonary Diseases 41, 605-644.

Hart, P. D. \& Rees, R. J. W. (1960). Effect of macrocyclon in acute and chronic pulmonary tuberculosis infection in mice as shown by viable and total bacterial counts. British Journal of Experimental Pathology 141, 414-421.

HarT, P. D. \& Valentine, R. C. (1963). Growth (without multiplication) of Mycobacterium lepraemurium in cell free medium. Journal of General Microbiology 32, 43-53.

Hart, P. D., Armstrong, J. A., Brown, C. A. \& DrAPER, P. (1972). Ultrastructural study on the behaviour of macrophages towards parasitic mycobacteria. Infection and Immunity 5, 803-807.

Hirsch, J. G. \& Fedorko, M. E. (1968). Ultrastructure of human leukocytes after simultaneous fixation with glutaraldehyde and osmium tetroxide and 'postfixation' in uranyl acetate. Journal of Cellular Biology 38, 615-627.

Jones, T. C. \& Hirsch, J. G. (1972). The interaction between Toxoplasma gondii and mammalian cells. II. The absence of lysosomal fusion with phagocytic vacuoles containing living organisms. Journal of Experimental Medicine 136, 1173-1194.

Kress, Y., Bloom, B. R., Wittner, M., Rowen, A. \& TANOWITZ, H. (1975). Resistance of Trypanosoma cruzi to killing by macrophages. Nature, London 251, 394-396. 
Noguiera, N. \& Conn, Z. (1976). Trypanosoma cruzi: mechanism of entry and intracellular fate in mammalian cells. Journal of Experimental Medicine 143, 1402-1420.

Sharp, K. (1973). Mycobacterium microti (Vole Bacillus): a method for viable counts within 21 days of culture. Applied Microbiology 25, 1023-1024.
Ungar, J., Muggleton, P. W., Dudley, J. A. R. \& Griffiths, M. L. (1962). Preparation and properties of a freeze-dried BCG vaccine of increased stability. British Medical Journal ii, 1086-1091. 